

\section{National Survey of E85 and Gasoline Prices}

\section{Technical Report NREL/TP-540-44254 \\ October 2008}

\section{P. Bergeron}

Prepared under Task No. FC08.0032

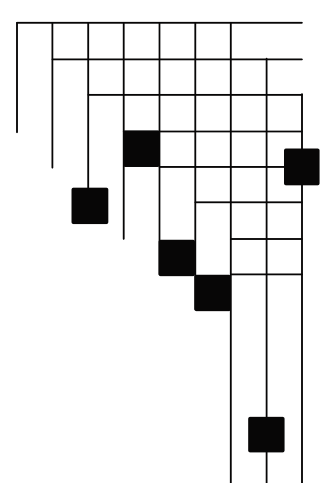

National Renewable Energy Laboratory 1617 Cole Boulevard, Golden, Colorado 80401-3393 303-275-3000 • www.nrel.gov

NREL is a national laboratory of the U.S. Department of Energy Office of Energy Efficiency and Renewable Energy

Operated by the Alliance for Sustainable Energy, LLC

Contract No. DE-AC36-08-GO28308 


\section{NOTICE}

This report was prepared as an account of work sponsored by an agency of the United States government. Neither the United States government nor any agency thereof, nor any of their employees, makes any warranty, express or implied, or assumes any legal liability or responsibility for the accuracy, completeness, or usefulness of any information, apparatus, product, or process disclosed, or represents that its use would not infringe privately owned rights. Reference herein to any specific commercial product, process, or service by trade name, trademark, manufacturer, or otherwise does not necessarily constitute or imply its endorsement, recommendation, or favoring by the United States government or any agency thereof. The views and opinions of authors expressed herein do not necessarily state or reflect those of the United States government or any agency thereof.

Available electronically at http://www.osti.gov/bridge

Available for a processing fee to U.S. Department of Energy and its contractors, in paper, from:

U.S. Department of Energy

Office of Scientific and Technical Information

P.O. Box 62

Oak Ridge, TN 37831-0062

phone: 865.576 .8401

fax: 865.576 .5728

email: mailto:reports@adonis.osti.gov

Available for sale to the public, in paper, from:

U.S. Department of Commerce

National Technical Information Service

5285 Port Royal Road

Springfield, VA 22161

phone: 800.553 .6847

fax: 703.605.6900

email: orders@ntis.fedworld.gov

online ordering: http://www.ntis.gov/ordering.htm 


\section{Table of Contents}

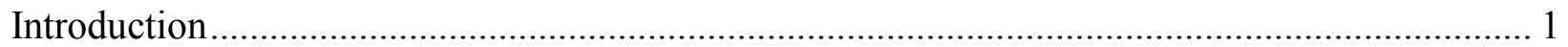

E85 and Gasoline Price Collection Results .................................................................... 2

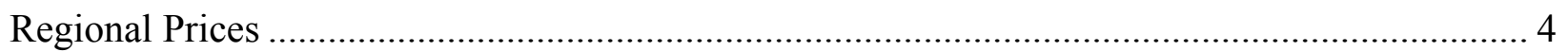

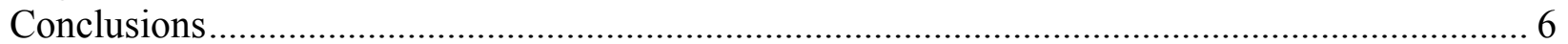

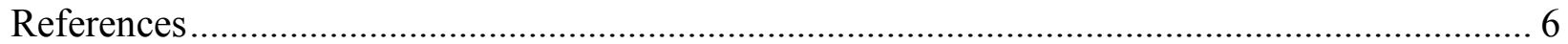

Appendix: Summary of Price Ratios, Prices, and Survey Responses over Time, by Region ........ 7 


\section{Introduction}

The objective of this study was to compare the prices of E85 (i.e., fuel containing $85 \%$ ethanol and $15 \%$ gasoline) and regular gasoline nationally and regionally over time for one year. The United States was divided into six sampling regions based on the seven Petroleum Administration for Defense Districts defined by the Energy Information Administration (EIA) and used in EIA's gasoline price reports [1]. To reduce the great disparity in the number of stations among the seven EIA regions, those regions were either split or combined to create the sampling regions shown in Table 1.

Table 1. Composition of Sampling Regions*

\begin{tabular}{l|c|l|c|c|}
\hline $\begin{array}{c}\text { Sampling } \\
\text { Region }\end{array}$ & \multicolumn{1}{|c|}{ ElA Region } & \multicolumn{1}{|c|}{ States } & $\begin{array}{l}\text { No. of Stations at } \\
\text { Start of Project }\end{array}$ \\
\hline 1 & $\begin{array}{l}\text { Central Atlantic and } \\
\text { Lower Atlantic }\end{array}$ & $\begin{array}{l}\text { NY, PA, NJ, MD, DE, DC, WV, } \\
\text { VA, NC, SC, GA, FL }\end{array}$ & 108 \\
\hline 2 & Midwest & MN & 303 \\
\hline 3 & $\begin{array}{l}\text { Midwest (eastern } \\
\text { states) }\end{array}$ & MI, IN, OH, KY, TN, IL & 323 \\
\hline 4 & $\begin{array}{l}\text { Midwest (western } \\
\text { states) }\end{array}$ & WI, SD, ND, IA, NE, MO, KS, OK & 313 \\
\hline 5 & $\begin{array}{l}\text { Gulf Coast } \\
\text { Rocky Mountain and } \\
\text { West Coast }\end{array}$ & $\begin{array}{l}\text { AL, MS, AR, LA, TX, NM } \\
\text { WA, OR, NV, AZ, CA, AK, HI MT, }\end{array}$ & 40 \\
\hline 6 & CO, WY, ID, UT & 67 \\
\hline
\end{tabular}

A sampling plan of the approximately 1,200 E85 stations that were operating nationwide at the time was devised to allow statistically significant regional and temporal comparisons of the data to be made within the limited data collection budget available. The Ethanol Promotion and Information Council (EPIC) used telephone surveys to collect the data in work done under a subcontract with the U.S. Department of Energy's National Renewable Energy Laboratory (subcontract number NEV-7-77419-01).

Telephone surveys of 120 individual stations that sell E85 were conducted every other week. Although 120 calls were made each time, fewer stations (81, on average) supplied both E85 and gasoline prices. To improve the temporal aspect of the survey, most of the stations were called three times over the first 6-month time period. The composition of each 120-station set was varied over time so that 600 different stations (roughly $50 \%$ of the total number) would be called over the 6-month period.

To properly weight the regional prices in the national average, each sampling region was represented in each sample set in proportion to the number of E85 stations in that region. To account for the fast-growing number of E85 stations, the sampling plan was redone based on the updated list of E85 stations for the second 6-month period. 


\section{E85 and Gasoline Price Collection Results}

Figures 1 and 2 show the national average prices of gasoline and E85 between July 2007 and June 2008, along with the standard deviation for each price. The average standard deviation over the year for gasoline was $\$ 0.14$ per gallon; for E85, the average standard deviation was $\$ 0.23$ per gallon.

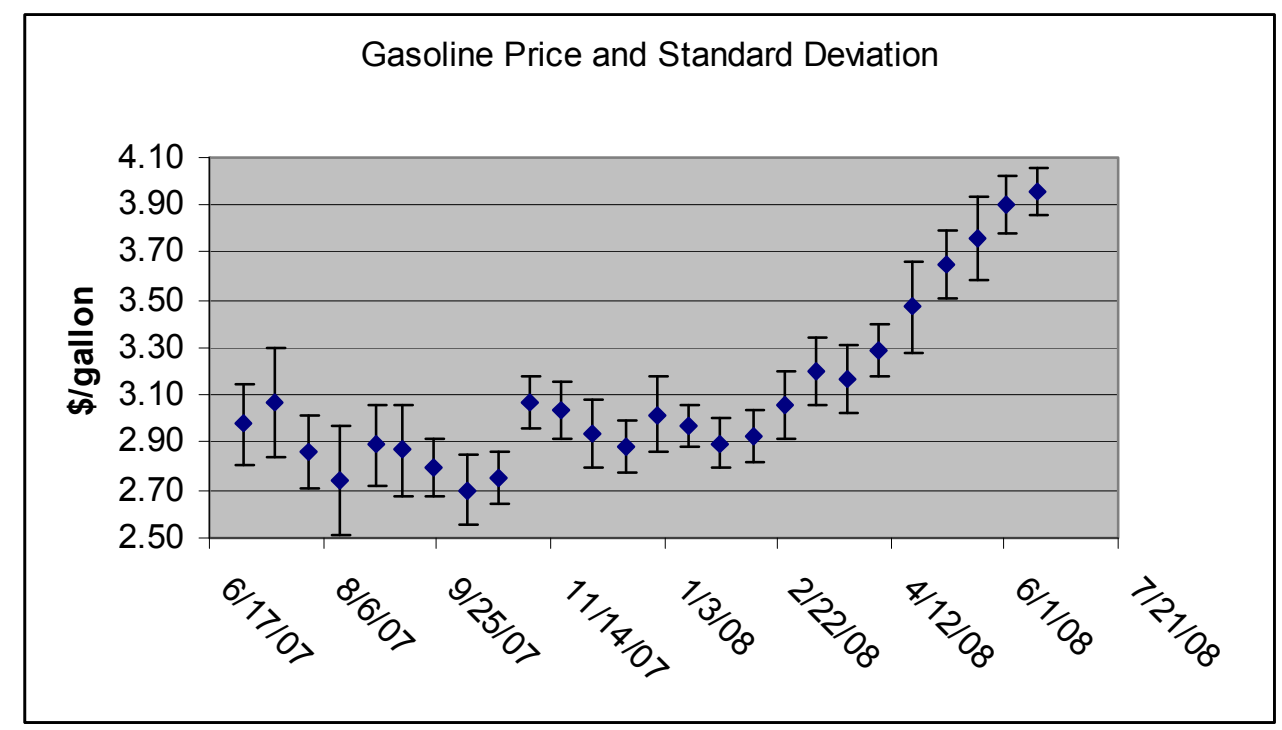

Figure 1. National average gasoline prices, with standard deviation

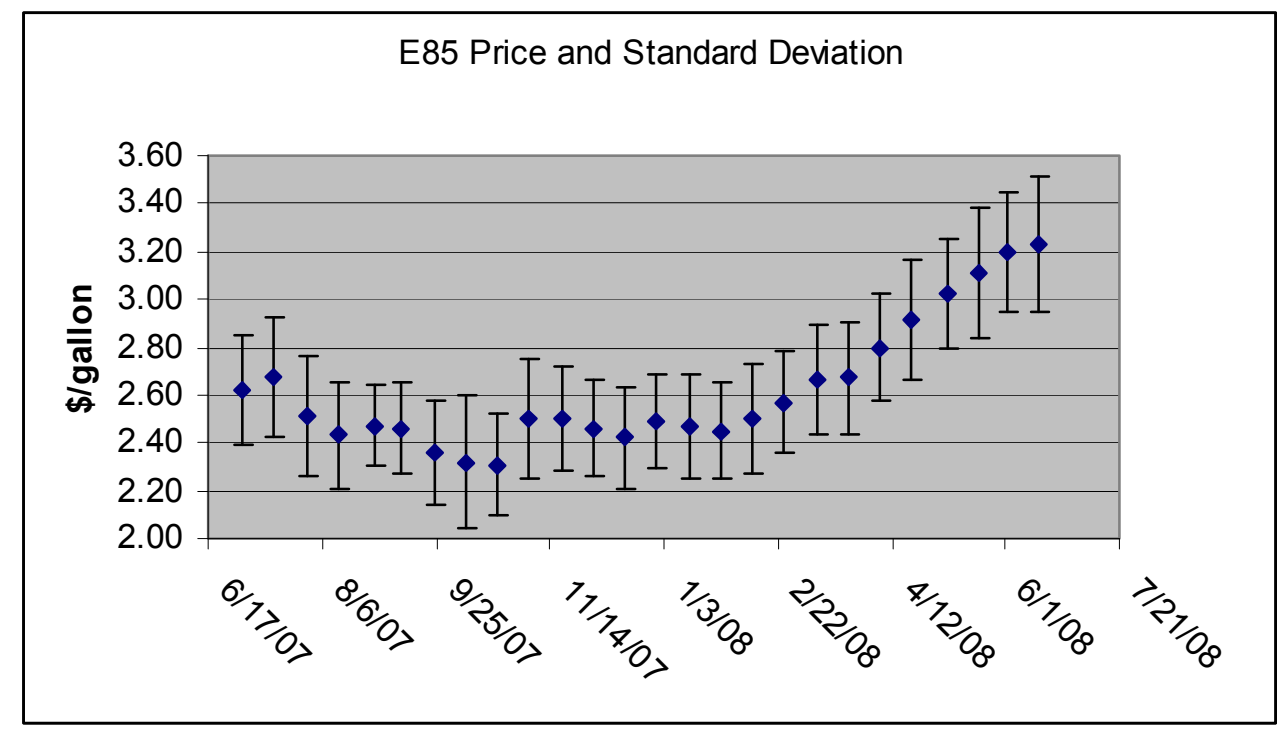

Figure 2. National average E85 prices, with standard deviation

Figure 3 shows the two prices together and illustrates both the volatility of prices over this time period as well as how closely the movements in gasoline prices were reflected in the E85 prices. It also shows the gap between the two prices widening somewhat as the price of gasoline increased beyond about $\$ 3$ per gallon. 


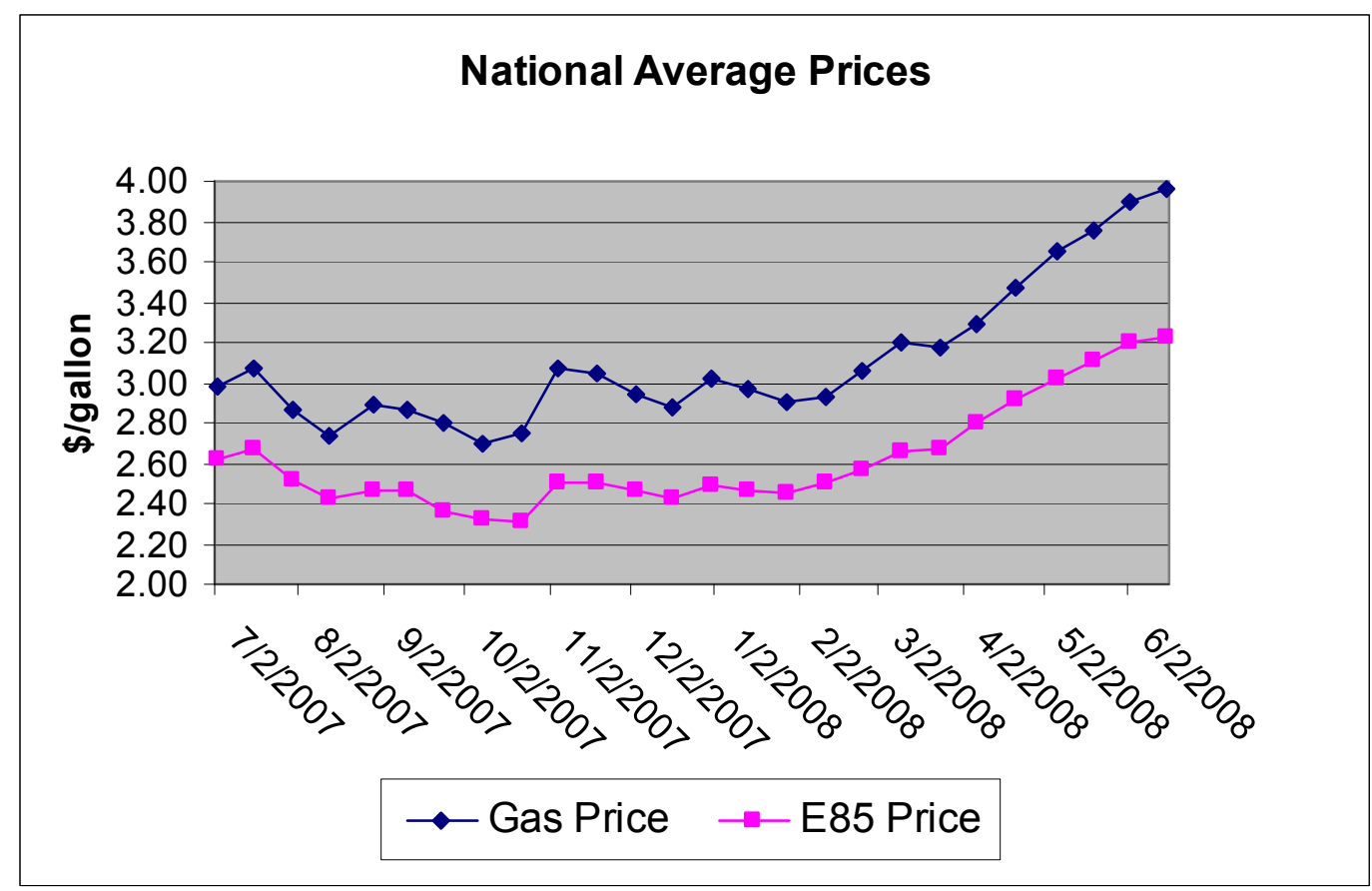

Figure 3. EPIC national average prices over time

Figure 4 is a plot of the national E85:gasoline price ratios over the time period. The ratios range from a high of 0.89 in August 2007 to a low of 0.82 in June 2008. Comparing the price ratio to the ratio of the energy content of E85 to that of gasoline- 0.71 for $85 \%$ ethanol in E85 up to 0.76 for $70 \%$ ethanol in E85 in some winter blends - allows us to determine which fuel costs less on a per-mile-driven basis. When the E85:gasoline price ratio is higher than the energy ratio, the consumer is paying more per mile for E85.

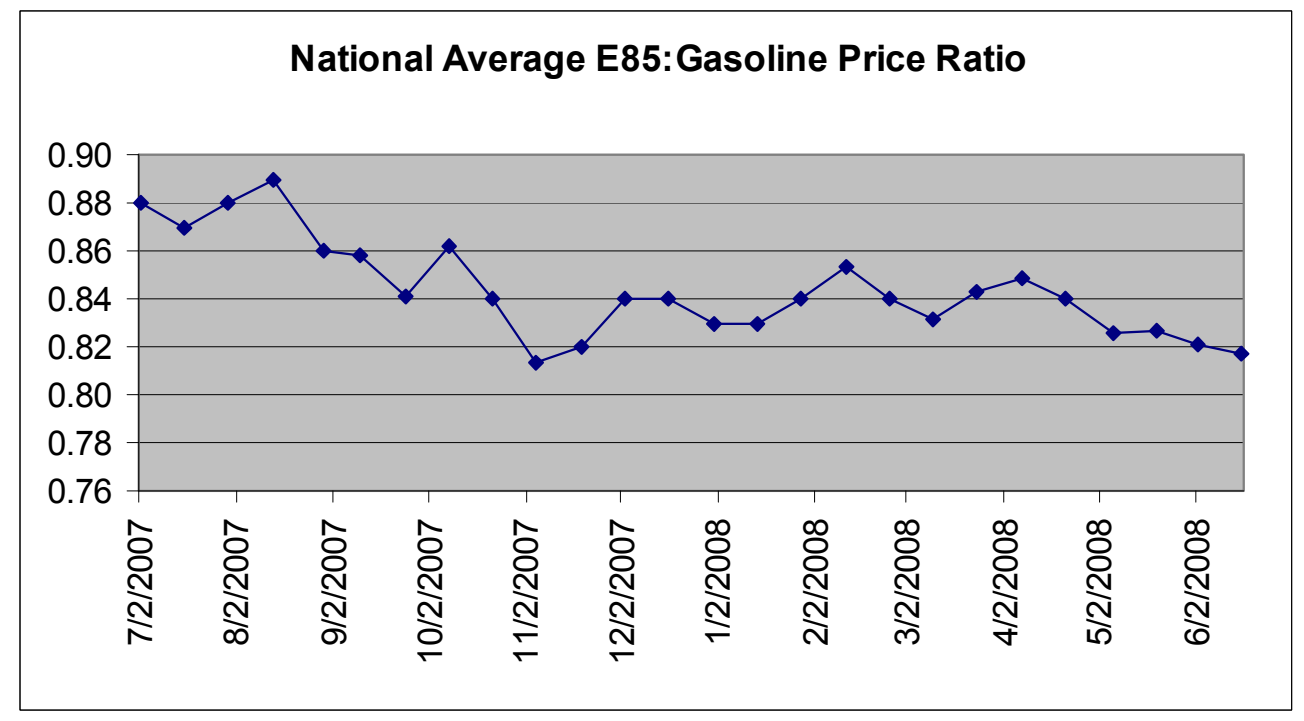

Figure 4. Price ratios over time 
Figure 5 shows that there is a slight downward trend in the E85:gasoline price ratio as the price of gasoline increases. This downward trend signifies an improvement in the per-mile cost of E85 relative to gasoline as the price of gasoline increases.

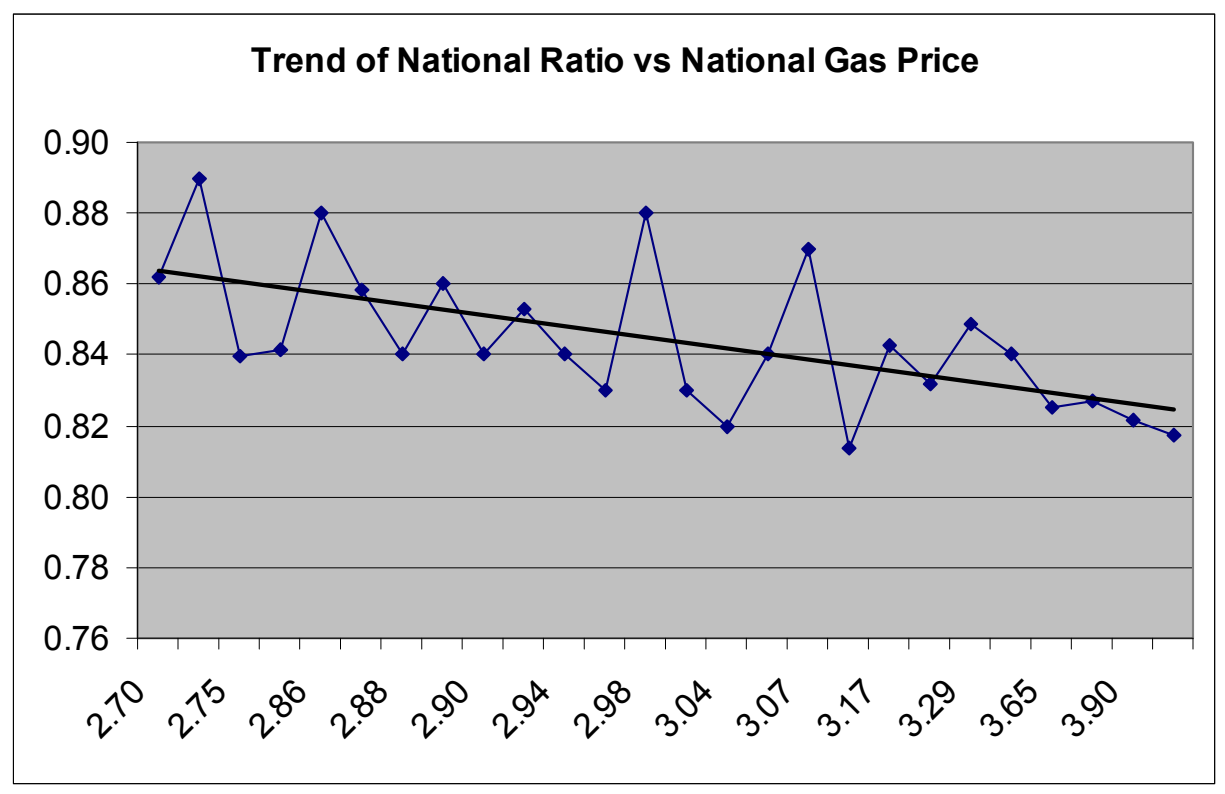

Figure 5. Trend of price ratios vs. gasoline price

\section{Regional Prices}

Table 2 lists the annual average regional E85:gasoline price ratios for the year of the study. These regions exhibited a fairly wide range of ratios, from a low of 0.83 for Minnesota to a high of 0.90 for the East Coast. The national average shown was calculated as the average of all reporting stations rather than as the average of the regional averages.

Table 2. Average Annual E85:Gasoline Price Ratio and Response Rates for 12 Months

\begin{tabular}{|c|l|c|c|c|}
\hline $\begin{array}{c}\text { Sampling } \\
\text { Region }\end{array}$ & \multicolumn{1}{|c|}{ EIA Regions } & $\begin{array}{c}\text { E85:Gasoline } \\
\text { Price Ratio }\end{array}$ & $\begin{array}{c}\text { Average } \\
\text { Response Rate }\end{array}$ & $\begin{array}{c}\text { Percent of } \\
\text { Target } \\
\text { Responses }\end{array}$ \\
\hline 1 & Central \& Lower Atlantic & 0.90 & 9.7 & $81 \%$ \\
\hline 2 & Midwest - Minnesota & 0.82 & 24.7 & $70 \%$ \\
\hline 3 & Midwest (eastern states) & 0.87 & 16.6 & $54 \%$ \\
\hline 4 & Midwest (western states) & 0.83 & 24.3 & $71 \%$ \\
\hline 5 & Gulf Coast & 0.88 & 1.6 & $44 \%$ \\
\hline 6 & West Coast \& Rocky & 0.86 & 4.1 & $77 \%$ \\
\hline & Mountain & 0.84 & 81 & $68 \%$ \\
\hline
\end{tabular}

The average responses over the year and the percent of the target response for each sampling region are also shown in Table 2. The very low number of responses from the Gulf Coast and West Coast/Rocky Mountain regions points out the particular weakness of the price data from those regions. 
Figures 6 and 7 show the volatility in the price ratio over time among the six regions. With the exception of the West Coast/Rocky Mountain region, the graphs show the spread tightening among the regions toward the end of the period, when the price of gasoline rose to its highest levels. The high price ratio volatility for the Gulf Coast and West Coast/Rocky Mountain regions is likely related to the low number of responses from those regions.

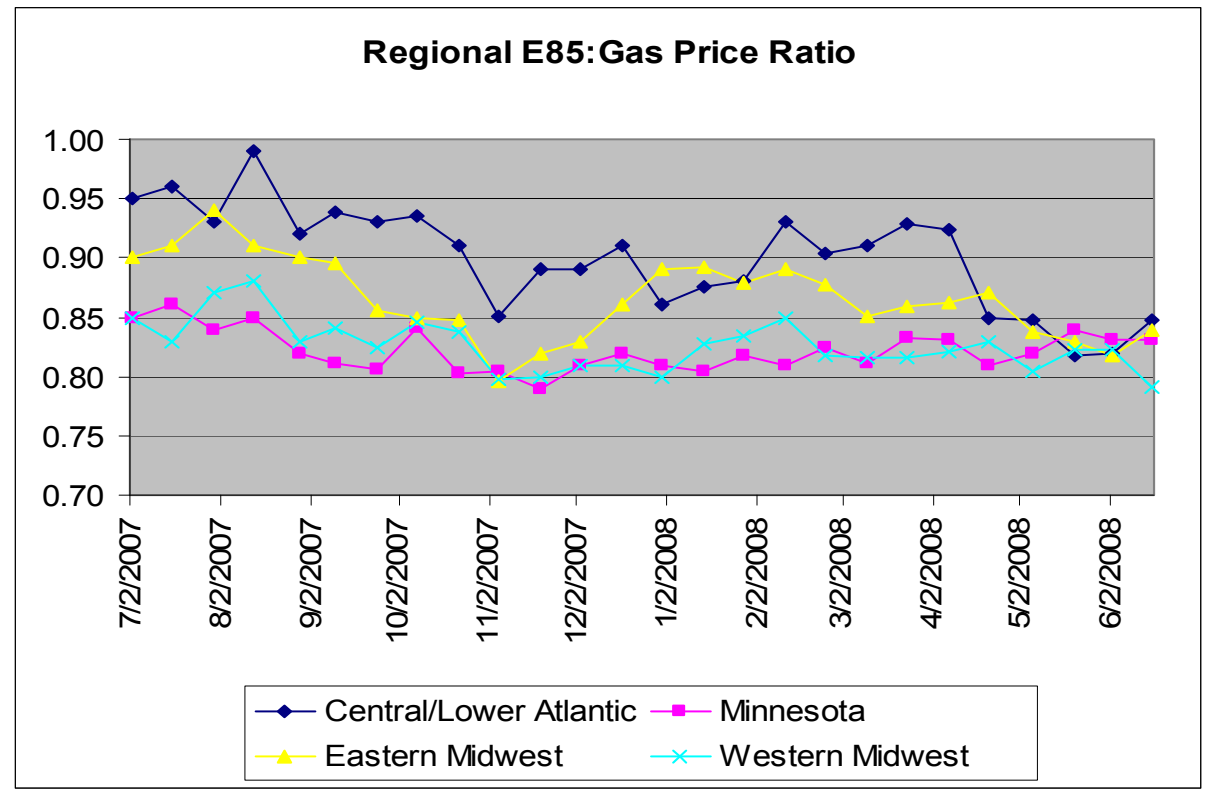

Figure 6. Regional average E85:gasoline price ratios over time

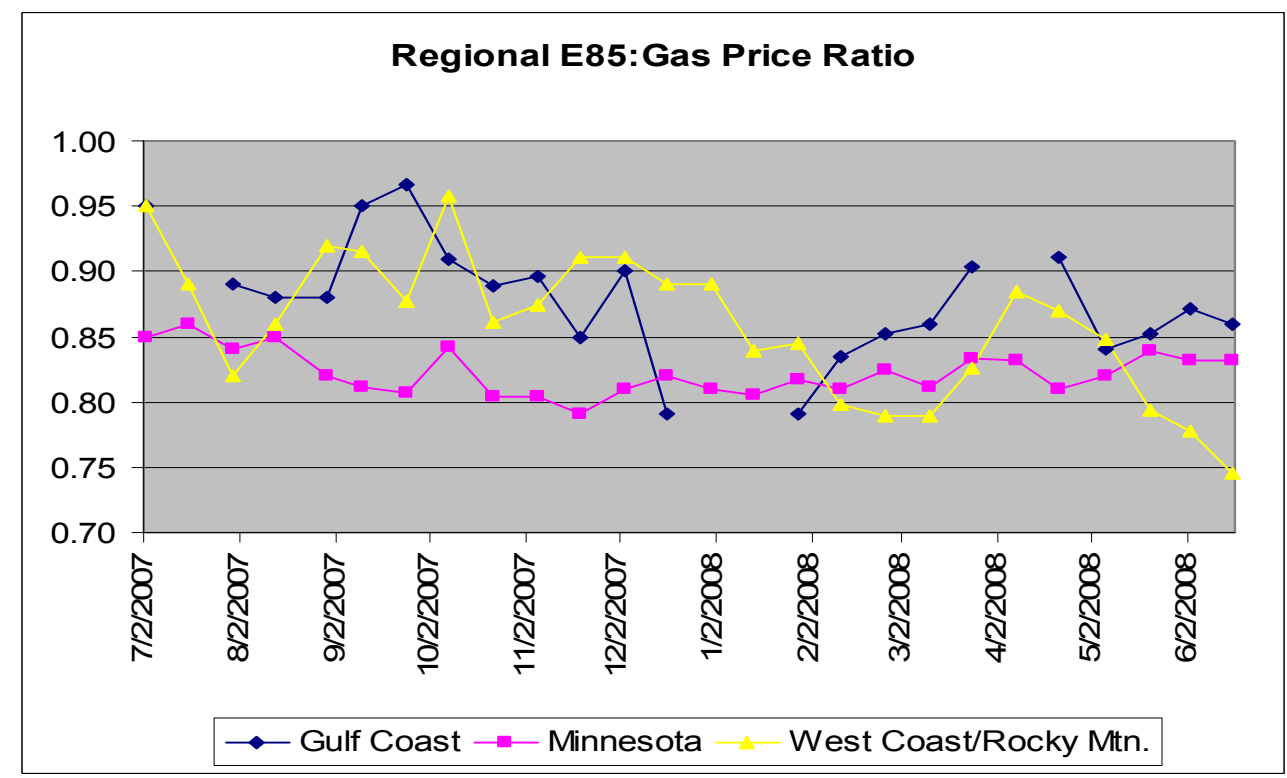

Figure 7. Regional average E85:gasoline price ratios over time

The appendix contains a table showing the regional price ratios, the national average prices and price ratios, and the number of responses over the data collection period. 


\section{Conclusions}

The national survey of E85 and gasoline prices for the period of time between July 2007 and June 2008 indicates the following:

- The price of E85 appears to closely track that of gasoline.

- The gap between E85 and gasoline appears to widen somewhat as the price of gasoline increases beyond about $\$ 3$ per gallon; i.e., the price of E85 increases more slowly than that of gasoline.

- The E85:gasoline price ratio was always higher than the E85:gasoline energy content ratio, signifying a higher per-mile cost for E85 in comparison to that of gasoline. The disparity diminished somewhat as the price of gasoline rose above $\$ 3$ per gallon.

- Minnesota exhibited the lowest E85:gasoline price ratio, 0.82, and the Central/Lower Atlantic Region the highest ratio, 0.90 .

- The average standard deviation for the price of gasoline during the survey period was $\$ 0.14$ /gallon; for E85, it was $\$ 0.23$ /gallon.

\section{References}

1. Energy Information Administration, "U.S. Gasoline Retail Prices - States in each Region," 2007, www.eia.doe.gov/oil_gas/petroleum/data_publications/wrgp/padd_page.html. Site accessed June 13, 2007. 
Appendix: Summary of Price Ratios, Prices, and Survey Responses over Time, by Region

\begin{tabular}{|c|c|c|c|c|c|c|c|c|c|c|c|c|c|c|c|c|c|c|c|c|c|c|c|c|c|c|c|}
\hline & Wk 1 & Wk 2 & Wk 3 & Wk 4 & Wk 5 & Wk 6 & Wk 7 & Wk 8 & Wk 9 & Wk 10 & Wk 11 & Wk 12 & Wk 13 & Wk 14 & Wk 15 & Wk 16 & Wk 17 & Wk 18 & Wk 19 & Wk 2 & Wk 21 & Wk 22 & Wk 23 & Wk 24 & Wk 25 & Wk 26 & \\
\hline & $7 / 2$ & $7 / 16$ & $7 / 30$ & $8 / 13$ & $8 / 29$ & \begin{tabular}{|l|}
$9 / 10$ \\
\end{tabular} & $9 / 24$ & $10 / 8$ & $10 / 22$ & $11 / 5$ & $11 / 19$ & $12 / 3$ & $12 / 17$ & $12 / 31$ & $1 / 14$ & $1 / 28$ & $2 / 11$ & $2 / 25$ & $3 / 10$ & $3 / 24$ & $4 / 7$ & $4 / 21$ & $5 / 6$ & $5 / 20$ & $6 / 2$ & \begin{tabular}{ll|}
$6 / 16$ \\
\end{tabular} & \\
\hline Region ${ }^{(1)}$ & Ratio & Ratio & Ratio & Ratio & Ratio & Ratio & Ratio & Ratio & Ratio & Ratio & Ratio & Ratio & Ratio & Ratio & Ratio & Ratio & Ratio & Ratio & Ratio & Ratio & Ratio & Ratio & Ratio & Ratio & Ratio & Ratio & Ave. \\
\hline 1. Central/Lower Atlantic & 0.95 & 0.96 & 0.93 & 0.99 & 0.92 & 0.94 & 0.93 & 0.93 & 0.91 & 0.85 & 0.89 & 0.89 & 0.91 & 0.86 & 0.88 & 0.88 & 0.93 & 0.90 & 0.91 & 0.93 & 0.92 & 0.85 & 0.85 & 0.82 & 0.82 & 0.85 & 0.90 \\
\hline 2. Minnesota & 0.85 & 0.86 & 0.84 & 0.85 & 0.82 & 0.81 & 0.81 & 0.84 & 0.80 & 0.80 & 0.79 & 0.81 & 0.82 & 0.81 & 0.80 & 0.818 & 0.81 & 0.82 & 0.81 & 0.83 & 0.83 & 0.81 & 0.82 & 0.84 & 0.83 & 0.83 & 0.82 \\
\hline 3. Eastern Midwest & 0.90 & 0.91 & 0.94 & 0.91 & \begin{tabular}{|l|}
0.90 \\
\end{tabular} & 0.90 & 0.86 & 0.85 & 0.85 & 0.80 & 0.82 & 0.83 & 0.86 & 0.89 & 0.89 & 0.879 & 0.89 & 0.88 & 0.85 & 0.86 & 0.86 & 0.87 & 0.84 & 0.83 & 0.82 & 0.84 & 0.87 \\
\hline 4. Western Midwest & 0.85 & 0.83 & 0.87 & 0.88 & \begin{tabular}{|l|}
0.83 \\
\end{tabular} & 0.84 & 0.82 & 0.85 & 0.84 & 0.80 & 0.80 & 0.81 & 0.81 & 0.80 & 0.83 & 0.834 & 0.85 & 0.82 & 0.82 & 0.82 & 0.82 & 0.83 & 0.80 & 0.82 & 0.82 & 0.79 & 0.83 \\
\hline 5. Gulf Coast & 0.95 & & 0.89 & 0.88 & \begin{tabular}{|l|}
0.88 \\
\end{tabular} & 0.95 & 0.97 & 0.91 & 0.89 & 0.90 & 0.85 & 0.90 & 0.79 & & & 0.791 & 0.83 & 0.85 & 0.86 & 0.90 & & 0.91 & 0.84 & 0.85 & 0.87 & 0.86 & 0.88 \\
\hline 6. West Coas & 0.95 & \begin{tabular}{|l|}
0.89 \\
\end{tabular} & 0.82 & 0.86 & \begin{tabular}{|l|}
0.92 \\
\end{tabular} & \begin{tabular}{|l|}
0.91 \\
\end{tabular} & 0.88 & 0.96 & 0.86 & 0.87 & 0.91 & 0.91 & 0.89 & 0.89 & \begin{tabular}{|l|} 
\\
\end{tabular} & 0.845 & 0.80 & 0.79 & 0.79 & 0.83 & 0.88 & 0.87 & 0.85 & 0.79 & 0.78 & 0.75 & 0.86 \\
\hline National Avg Ratio ${ }^{(2)}$ & \begin{tabular}{|l|l|}
0.88 \\
\end{tabular} & 0.87 & 0.88 & 0.89 & 0.86 & 0.86 & 0.84 & 0.86 & 0.84 & 0.81 & 0.82 & 0.84 & 0.84 & 0.83 & 0.83 & 0.84 & 0.85 & 0.84 & 0.83 & 0.84 & 0.85 & 0.84 & 0.83 & 0.83 & 0.82 & 0.82 & 0.84 \\
\hline Nat. Avg Gas Price ${ }^{(2)}$ & 2.98 & 3.07 & 2.86 & 2.74 & 2.89 & 2.87 & 2.80 & 2.70 & 2.75 & 3.07 & 3.04 & 2.94 & 2.88 & 3.02 & 2.97 & 2.90 & 2.93 & 3.06 & 3.20 & 3.17 & 3.29 & 3.47 & 3.65 & 3.76 & 3.90 & 3.96 & 3.11 \\
\hline Responses & 81 & 86 & 75 & 81 & 89 & 85 & 87 & 87 & 87 & 80 & 78 & 79 & 75 & 61 & 62 & 66 & 81 & 76 & 82 & 84 & 86 & 86 & 82 & 84 & 78 & 74 & 79.7 \\
\hline National Ave. E85 Price ${ }^{(2)}$ & 2.62 & 2.67 & 2.51 & 2.43 & 2.47 & 2.46 & 2.36 & 2.32 & 2.31 & 2.50 & 2.50 & 2.46 & 2.42 & 2.49 & 2.47 & 2.45 & 2.50 & 2.57 & 2.66 & 2.67 & 2.8 & 2.91 & 3.02 & 3.11 & 3.2 & 3.23 & 2.62 \\
\hline
\end{tabular}




\section{REPORT DOCUMENTATION PAGE}

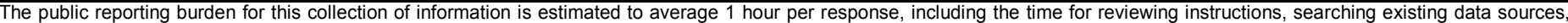

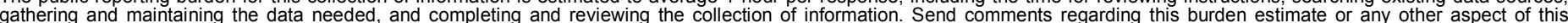

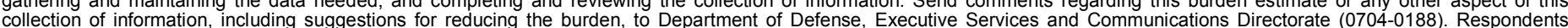

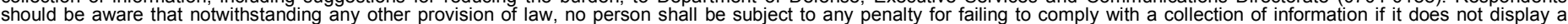

should be aware that notwithstand

PLEASE DO NOT RETURN YOUR FORM TO THE ABOVE ORGANIZATION.

\begin{tabular}{l|l|l|l} 
1. REPORT DATE $(D D-M M-Y Y Y Y)$ & 2. & REPORT TYPE & 3. DATES COVERED (FrOm - TO)
\end{tabular}

October 2008

Technical Report

4. TITLE AND SUBTITLE
National Survey of E85 and Gasoline Prices

5a. CONTRACT NUMBER

DE-AC36-08-GO28308

5b. GRANT NUMBER

5c. PROGRAM ELEMENT NUMBER

6. AUTHOR(S)

P. Bergeron

5d. PROJECT NUMBER

NREL/TP-540-44254

5e. TASK NUMBER

FC08.0032

5f. WORK UNIT NUMBER
7. PERFORMING ORGANIZATION NAME(S) AND ADDRESS(ES)

National Renewable Energy Laboratory

1617 Cole Blvd.

Golden, CO 80401-3393
8. PERFORMING ORGANIZATION REPORT NUMBER

NREL/TP-540-44254

9. SPONSORING/MONITORING AGENCY NAME(S) AND ADDRESS(ES)

10. SPONSOR/MONITOR'S ACRONYM(S) NREL

11. SPONSORING/MONITORING AGENCY REPORT NUMBER

12. DISTRIBUTION AVAILABILITY STATEMENT

National Technical Information Service

U.S. Department of Commerce

5285 Port Royal Road

Springfield, VA 22161

\section{SUPPLEMENTARY NOTES}

14. ABSTRACT (Maximum 200 Words)

Study compares the prices of E85 and regular gasoline nationally and regionally over time for one year. The United States was divided into six sampling regions based on the seven Petroleum Administration for Defense Districts defined by the Energy Information Administration (EIA) and used in EIA's gasoline price reports. A sampling plan of the approximately 1,200 E85 stations that were operating nationwide at the time was devised to allow statistically significant regional and temporal comparisons of the data to be made within the limited data collection budget available.

15. SUBJECT TERMS

Clean Cities; E85; ethanol; flexible fuel vehicles; FFVs; alternative fuel vehicles; AFVs; fuel prices

\begin{tabular}{|c|c|c|}
\hline $\begin{array}{l}\text { a. REPORT } \\
\text { Unclassified }\end{array}$ & $\begin{array}{l}\text { b. ABSTRACT } \\
\text { Unclassified }\end{array}$ & $\begin{array}{l}\text { c. THIS PAGE } \\
\text { Unclassified }\end{array}$ \\
\hline
\end{tabular}

\begin{tabular}{l|l} 
17. LIMITATION \\
OF ABSTRACT \\
UL
\end{tabular}

19a. NAME OF RESPONSIBLE PERSON

19b. TELEPHONE NUMBER (Include area code) 